\title{
Late Development of Diabetes mellitus after Interferon-Alfa and Ribavirin Therapy for Chronic Hepatitis C: A Case Report
}

\author{
Sivasankara Radhakrishnan ${ }^{\mathrm{a}}$ Amal Upadhyay ${ }^{\mathrm{a}}$ Nihar Mohan $^{\mathrm{a}}$ Anjan Dhar ${ }^{\mathrm{a}}$ \\ Harbhajan Kaur Walia ${ }^{\text {a }}$ Ghazi Zubaidi ${ }^{\text {b }}$
}

Departments of ${ }^{\mathrm{a}}$ Gastroenterology and ${ }^{\mathrm{b}}$ Endocrinology, The Royal Hospital, Muscat, Oman

\author{
Key Words \\ Hepatitis C · Alfa-interferon · Immune-mediated \\ diabetes mellitus
}

\begin{abstract}
Objective: To report the late development of immunemediated diabetes mellitus after completion of alfa-interferon therapy for hepatitis $\mathrm{C}$ in an Asian patient. Clinical Presentation and Intervention: A 50-year-old male with chronic hepatitis $C$ received treatment with alfa-interferon and ribavirin for 52 weeks. He developed immune-mediated diabetes mellitus with low C-peptide and positive antiglutamic acid decarboxylase antibody after completion of therapy. The hepatitis $\mathrm{C}$ infection was eradicated, but he continued to be diabetic requiring insulin therapy during the follow-up. Conclusion: This report shows that immune-mediated diabetes mellitus can occur as a late complication of alfa-interferon therapy.
\end{abstract}

Copyright (c) 2005 S. Karger AG, Basel

\section{Introduction}

It is estimated that there are some 170 million chronic hepatitis C-infected people throughout the world. Hepatitis $\mathrm{C}$ virus (HCV) accounts for approximately $20 \%$ of acute hepatitis, $70 \%$ with chronic hepatitis and $40 \%$ of end-stage cirrhosis [1]. The carrier rate for HCV in Oman is about $1.2 \%$ [personal commun. from blood bank].

$\mathrm{HCV}$ infection of the liver has been reported to be associated with an increased prevalence of autoimmune diseases and type- 2 diabetes mellitus. Treatment of chronic hepatitis due to HCV with alfa-interferon has also been reported to induce autoimmune diseases such as autoimmune hepatitis, Hashimoto's thyroiditis and immune-mediated diabetes mellitus [2]. Most reports of diabetes mellitus in this situation occur within a few months after initiation of therapy [3-5]. We report a case of chronic hepatitis $\mathrm{C}$ who received alfa-interferon and ribavirin treatment and later developed immune-mediated diabetes mellitus requiring insulin, after completing 52 weeks of therapy.

\section{Case Report}

A 50-year-old Asian male weighing $80 \mathrm{~kg}$ with a body mass index of 28 was evaluated in the Gastroenterology Clinic, The Royal Hospital, Muscat, Oman for asymptomatic elevation of liver transaminases. He denied a past history of jaundice, transfusion of blood products and had no other risk factors for acquisition of hepatitis viruses. He consumed alcohol occasionally. He was not known to be suffering from diabetes mellitus or any autoimmune disease.

Physical examination revealed that he was anicteric, not anemic, and did not have any stigmata of chronic liver disease. Abdominal examination did not reveal any hepatosplenomegaly or ascites. The laboratory parameters were as follows: $\mathrm{Hb} 16.4 \mathrm{~g} / \mathrm{dl}$,

\section{KARGER}

Fax +4161306 1234 E-Mail karger@karger.ch www.karger.com
Dr. S. Radhakrishnan, FRCP (Edin)

Gastroenterology Division

The Royal Hospital, PO Box 1331, CPO 111

Muscat (Oman)

Tel./Fax+968594461, E-Mail jagan01@omantel.net.om 
WBC $6.2 \times 10^{9} / 1$, platelets $240 \times 10^{9} / 1$, prothrombin time $14.6 \mathrm{~s}$, bilirubin $12 \mu \mathrm{mol} / 1$, albumin $42 \mathrm{~g} / 1$, globulin $30 \mathrm{~g} / \mathrm{l}$, ALT $164 \mathrm{IU} / 1$ (normal <60), AST $60 \mathrm{IU} / 1$ (normal <40), GGT 46 IU/1, ALP $80 \mathrm{IU} / 1$ (normal $<112$ ), creatinine $80 \mu \mathrm{mol} / \mathrm{l}$. The patient was found to be positive for HCV antibody by an ELISA test (Axsym ${ }^{\circledR}$, Abbott GmBH Diagnostica, Germany). The HCV was of genotype 3 and the viral load was estimated to be 1.06 million units/ml (Amplicor, Hoffmann-La Roche Ltd., Germany). Hepatitis B virus markers were negative, as was the autoantibody profile (antinuclear factor, anti-smooth muscle antibody, LKM1 antibody). The serum ceruloplasmin and alpha-1-antitrypsin levels were within normal limits. The liver biopsy showed mild inflammation and piecemeal necrosis: grade II inflammation and stage I fibrosis (HAI scoring). The patient was started on treatment for chronic hepatitis $\mathrm{C}$ with alfainterferon 3 million units (Roferon, interferon alfa-2a, Roche Pharmaceuticals, Basel, Switzerland) subcutaneously, thrice a week and ribavirin $1,200 \mathrm{mg} /$ day in August 2000. At the start of therapy, random blood glucose was $6.4 \mathrm{mmol} / 1$ and blood glucose at 12, 24, 36 and 48 weeks was within normal range. He began to experience polydipsia and polyuria around the time of completion of the treatment at 52 weeks. The random blood sugar at this time was $18 \mathrm{mmol} / \mathrm{l}$ and he was admitted for control of hyperglycemia. The liver function tests showed normalization of ALT to $24 \mathrm{IU} / 1$. HCVRNA by PCR was negative at 24 weeks after initiation of therapy and HCV viral load was undetectable at 52 weeks. This remained undetectable for up to 24 weeks after the treatment was completed.

In October 2001, he had achieved reasonable glycemic control, but $\mathrm{HbA} 1 \mathrm{C}$ was $12 \%$. C-peptide was $0.3 \mathrm{ng} / \mathrm{ml}$ (normal range $0.5-$ $4.5 \mathrm{ng} / \mathrm{ml}$ ), pancreatic islet cell antibodies (ICA) $<3$ (normal), and antiglutamic acid decarboxylase (anti-GAD) antibody titer was $49.3 \mathrm{kU} / 1$ (normal less than $0.9 \mathrm{kU} / \mathrm{l}$ ). The presence of anti-GAD antibody and a low C-peptide are consistent with autoimmune type- 1 diabetes mellitus. The patient is currently euglycemic but requires 44 units/day of Mixtard 30HM insulin (Biphasic 30:70 human insulin suspension, Novo Nordisk A/S, Denmark). He continues to be negative for HCV RNA 10 months after completion of antiviral therapy.

\section{Discussion}

$\mathrm{HCV}$ infection has been linked to an increased prevalence of non-insulin-dependent diabetes mellitus (type-2 diabetes mellitus) in a number of reports [6,7]. While the liver is important for glucose homeostasis and diabetes may occur more often in patients with HCV infection because of hepatocyte dysfunction and insulin resistance, it is also possible that autoimmune phenomena related to $\mathrm{HCV}$ may induce diabetes mellitus as reported in cases of autoimmune diseases such as Hashimoto's thyroiditis, glomerulonephritis, Sjögren's disease and cryoglobulinemia [8]. HCV infection results in an increased occurrence of both type- 1 or type- 2 diabetes.

Alfa-interferon therapy has been reported to induce multiple autoantibodies and type- 1 diabetes mellitus in patients with chronic HCV infection [3-9], but Dicesare [10] has reported that up to $13 \%$ of patients developed insulin autoantibody without the development of diabetes [10]. Most reports [3-5] described the development of insulin-dependent diabetes mellitus during the early phase of therapy with interferon-alfa for chronic hepatitis $\mathrm{C}$, although the disease can present up to 4 years after completion of therapy with interferon. These patients were found to be positive for one or more multiorgan antibodies such as ICA-IgG, anti-GAD antibody, anti-insulin antibodies, anti-insulin receptor antibody and thyroid microsomal autoantibodies. HLA tissue typing demonstrates an autoimmune disease phenotype of HLA-DR 1, 3, 8-allele type.

Type-1 diabetes mellitus is regarded as a chronic autoimmune disease caused by selective destruction of the insulin-producing beta cells. The disease is mediated by $\mathrm{T}$ cells but autoantibodies are well-established markers for an ongoing autoimmune process within the islets. Individuals with more than one autoantibody have a higher risk of developing type-1 diabetes [11]. In the majority of previous reports [3-5] the development of antibodies and hyperglycemia occurred within a few months of starting alfa-interferon therapy. But in this patient, type-1 insulin-dependent diabetes mellitus developed around the time of completion of 52 weeks of alfa-interferon therapy. The positive anti-GAD antibodies support the autoimmune nature of the disease induced by even low-dose alfa-interferon therapy.

There is little evidence to suggest that HCV infection by itself triggers autoimmune destruction of the beta cells in the pancreatic islets. It has been shown that HCV-infected patients are hyperinsulinemic and have increased peripheral resistance to insulin, features which are compatible with type-2 non-insulin-dependent diabetes mellitus. Of the few HCV-positive diabetics who have documented insulin and beta cell autoantibodies, many have received treatment with alfa-interferon [5]. Based on these facts, we believe that the development of anti-GAD antibody-positive insulin-dependent (type-1) diabetes mellitus in this patient was induced by alfa-interferon therapy. Ribavirin is not known to induce diabetes mellitus or potentiate the effect of alfa-interferon therapy in inducing autoantibodies. There is only one other published report [12] of diabetic ketoacidosis induced by alfainterferon and ribavirin therapy in a patient with hepatitis $\mathrm{C}$ and this patient also had a low C-peptide level, high anti-GAD antibody but undetectable anti-islet cell antibody [12]. Screening for autoantibodies specific for type1 diabetes prior to initiation of alfa-interferon therapy for 
chronic hepatitis $\mathrm{C}$ is not recommended, although some investigators believe that this should form part of the pretherapy evaluation in patients with a family history of diabetes. Currently it is not clear how long after completion of therapy with interferon diabetes can still develop or whether patients need to be monitored for blood glucose levels on a long-term basis. We recommend that blood glucose monitoring should be an essential part of follow-up of these patients during and after completion of therapy.

\section{Conclusion}

This case shows that insulin-dependent (type-1) diabetes mellitus should be recognized as a potential side effect of combination therapy of chronic hepatitis $\mathrm{C}$ both during treatment and in the long term.

\section{References}

1 Cohen J: The scientific challenge of hepatitis C. Science 1999;285:26-30.

$\checkmark 2$ Allison MED, Wreghitt T, Palmer CR, Alexander GJM: Evidence of a link between hepatitis $\mathrm{C}$ virus infection and diabetes mellitus in a cirrhotic population. J Hepatol 1994;21:11351139.

$\checkmark 3$ Caronia S, Taylor K, Pagliaro L, Carr C, Palazzo U, Petrik J, et al: Further evidence for an association between non-insulin dependent diabetes mellitus and chronic hepatitis $\mathrm{C}$ virus infection. Hepatology 1999;30:1059-1063.

$\checkmark 4$ Mehta SH, Brancati GL, Sulkowski MS, Strathdee SA, Szklo M, Thomas DL: Prevalence of type-2 diabetes mellitus among persons with hepatitis $\mathrm{C}$ virus infection in the United States. Ann Intern Med 2000; 133:592599.
5 Fabris P, Betterle C, Greggio NA, Zanchetta R, Bosi E, Biasin MR, et al: Insulin-dependent diabetes mellitus during alfa-interferon therapy for chronic viral hepatitis. J Hepatol 1998; 28:514-517.

-6 Uto H, Matsuoka H, Murata M, Okamoto T, Miyata Y, Hori T, et al: A case of chronic hepatitis $\mathrm{C}$ developing insulin-dependent diabetes mellitus associated with various autoantibodies during interferon therapy. Diabetes Res Clin Pract 2000;49:101-106.

7 Recasens M, Aguilera E, Ampurdanes S, Sanches Tapias JM, Simo O, Casamitjana R, et al: Abrupt onset of diabetes during interferon-alpha therapy in patients with chronic hepatitis C. Diabet Med 2001;18:764-767.

$>8$ Eibl N, Gschwantler, Ferenci P, Eibl MM, Weiss W, Schernthaner G: Development of insulin-dependent diabetes mellitus in a patient with chronic hepatitis $\mathrm{C}$ during therapy with interferon-alpha. Eur J Gastroenterol Hepatol 2001;13:295-298.
$>9$ Wasmuth HE, Stolte C, Geier A, Gartung C, Matern S: Induction of multiple autoantibodies to islet cell antigens during treatment with interferon alfa for chronic hepatitis C. Gut 2001;49:596-597.

10 Dicesare E: Interferon-alpha therapy may induce insulin autoantibody development in patients with chronic viral hepatitis. Dig Dis Sci 1996;41:1672-1677.

11 McLaren NK, Lan M, Coutant R, et al: Only multiple autoantibodies to islet cells (ICA), insulin, GAD65, IA-2 and IA-2 predict immunemediated (type-I) diabetes in relatives. J Autoimmun 1999;12:279-287.

12 Bhatti A, McGarrity TJ, Gabbay R: Diabetic ketoacidosis induced by alfa interferon and ribavirin treatment in a patient with hepatitis C. Am J Gastroenterol 2001;96:604-605. 